\title{
Ensemble Organization of the Band of Fela Anikulapo-Kuti
}

*Albert OIKELOME

\begin{abstract}
The achievements of Fela Anikulapo Kuti in the field of popular music assumed an epic proportion both at national and international level. His development and popularization of Afrobeat genre is one of his greatest achievement in the field of popular music in Nigeria. However, beyond the musical skills of this great musician is his ability to galvanize both human and material resources into one unique brand. For indeed, beyond the artistic prowess of Fela lies the ability to manage and coordinate a large band both within and outside the stage. This paper therefore examines the administrative set up of the Afrobeat band of Fela Anikulapo Kuti. The paper will also consider the rehearsal procedures and techniques employed by Fela as witnessed by the band members. Through an in-depth interview with key members of his band that are still alive, the paper considers the administrative styles adopted by Fela Anikulapo Kuti and how present day musicians can also adapt such styles in managing the big band in the $21^{\text {st }}$ century.
\end{abstract}

Keywords: Big band, Ensemble, Globalization, Creative process.

\section{Introduction}

We live in an era of increased advancement in technology. This trend has affected the way music production is being practiced in the country. Back in FelaAnikulapo-Kutiôs days, the big band phenomenon was in vogue. Managing a retinue of singers, dancers, musicians and administrative was very challenging. However, contrary to the views of sceptics about Felaôs ability to manage a large band effectively, Fela ran a highly effective and organized band. From the recruitment and training of musicians to the

*Albert OIKELOME of the Department of Creative Arts

University of Lagos, Lagos Email: oikelomealbert@yahoo.com 
rehearsal procedures, Fela maintained a high level of musicianship and administrative sagacity that imparted the band positively. The purpose of this paper therefore is to examine Fela Anikulapo Kuti both as a musician and manager. It explores key factors responsible for the success of the Egypt 80 band and how the upcoming bandleaders can benefit from the experience. Information was gathered from key members of Felaôs band that are still alive. The discourse provides a template that future Afrobeat exponents can adapt for a successful administration of the big band.

\section{Fela's band}

Afrobeat is a unique music genre that first emerged in the late 1960s amid the rapidly changing postcolonial terrain of Lagos, Nigeria. Created by Fela Anikulapo-Kuti (1938-1997), the genre blends scathing anti-establishment lyrics with Yoruba traditional music and Western forms, particularly jazz (Dosunmu, 2010). Throughout his lifetime, Fela held hegemonic sway over afrobeatôs stylistic and ideological trajectories, making him one of the best musicians to have emerged from the continent of Africa. However, his success was borne from his ability to create and manage the band. From the early stage of his music career, Fela had been managing music bands. His popular music experience in London started with the formation of a highlife group with his friend Braimah who was also in London to study law. They named the group ñHighlife Rakersò. Later on, the groupôs name was changed to ñKoolaLobitosò comprising members drawn from Nigeria, Ghana, and the West Indies. The KoolaLobitos venture was extremely successful and lucrative as it kept the band busy almost every weekend and provided financial relief to his members (Coker, 2004). Fela arrived in Lagos in 1963 to find highlife music as the most popular music genre of the time. Eager for fame and popularity, he refused to join the highlife bandwagon. He formed his own band called the "FelaRansomeKuti Quintet" and later the "KoolaLobitos" band. The band experimented with a mixture of highlife and jazz. His journey to America in 1969 at the peak of the Nigerian civil war marked the turning point in his career. He met 
and fell in love with Sandra Smith, a Black Panther and civil rights activist who radically altered his political vision. He then realized the need to change his musical direction. He embraced PanAfricanism, using Afrobeat music as a weapon of struggle and political emancipation. On his return from America, Felá released a hit album titled 'London scene' in 1970 and in 1971, changed his bandôs name fromKoolaLobitos to the 'Africa 70' (Moore, 1982). The 1980s witnessed further development of Afrobeat from what it used to be in the seventies. The band in the seventies comprised major instrumentalists from the highlife bands that existed then. They were also knowledgeable in music theory. However, the expansion of the band from thirty to about fifty members saw the inclusion of instrumentalists who found their way in on the basis of skills and the ability to play by rote. Another major innovation to the band was the change of the name from Africa 70 to Egypt 80.

\section{The study}

The study examines the organizational structure of the band Fela ran from the 70ôs till the 80ôs. In undertaking the study, several band members of the band were contacted and interviewed. This would give a broad understanding of the modus operandi of the band. The is an investigation into the ensemble organization of Felaôs Afrobeat band. It will also relate it to the present state ensemble organization of bands and the challenges being faced by the musicians in its organization and maintenance.

\section{Organization of Afrobeat Band}

The organisation of Afrobeat band comprised four sections namely: the vocal, the instrumental, the dance and the administrative section. The vocal section comprised the song leader and the singers while the instrumentalist section comprised the band leader, and the instrumentalists. At the dance section, we have the dance tutor and the dancers while the administrative section comprised the band manager, the sound engineer, the accountant, and the stage manager. The band was run by the overall leader and founder, FeláAníkúlápòKútì. Using Feláôs band as a model, each section and their role in the group are discussed. 


\section{The Leader}

The overall leader of the group was FeláAníkúlápòKútì. He was responsible for the overall coordination of the group with all the sectional heads reporting directly to him. He was also the lead singer, composer, arranger and the creative persona of the band. As the leader of the band, he was vested with powers of deciding when and where performances would take place both within and outside the country. He also fixed the time for all the rehearsal sessions with each section of the band. Furthermore, he ensured prompt payment of the salaries of members, including the power to hire and fire any erring member. In a nutshell, all the members of the band including the administrative section were under his supervision.

\section{Band Manager}

The organisation of the band was hinged on an administrative structure with several components. The band was registered under the name ñKalakuta Company Limitedò with the band manager ${ }^{1}$ as the head of administration. His functions included the supervision of the administrative arm of the company which comprised the accounting section, the ticket sales, the bar section, the clinic, the studio section and the security section of the organisation. As the chief financial officer of the group, he ensured prompt payment of salaries and other financial matters to all members of the band on a weekly basis. He also handled the travelling arrangements of the band on both national and international engagements.

The first manager of the group was Benson Idonije. In an interview with the researcher, he stated that he was approached by Feláto manage the group when it started in 1965. Since they were both members of staff of the Nigerian Broadcasting Corporation, they had no difficulty in seeing and charting out ways of making the group successful. He however confessed that the first few years as the manager of the group was very challenging since the gate fees they were making was very little. However, things took a positive turn from the early 70s when Feláreturned from America 
with a redefined music he called ñAfrobeatò. As the manager of the band, he had to be at all the engagements and supervised the proceedings in order to have a hitch free program. He claimed Felá was a very pleasant person to work with but was a perfectionist to the core, which sometimes led him to keep the instrumentalists working longer than usual.Working with Felá as the first manager was no mean feat. Benson recounted the problems they went through even on a simple matter of securing press coverage for Felá:

We were made to record the music on tape for the features Editor of Daily Times to listen to. As if that was not enough, we were made to provide a reel to reel tape machine to play back the tape, which we did. Feláôs music was censored by the government press because of the lyrics they termed sensational and unacceptable for public consumption, hence the need to censor whatever he said to the public (2006).

Under Benson Idonijeôs management, the bandôs initial outings attracted only a few people at the early stage because of the negative attitude people had of highlife jazz. However, fortune smiled on them from the 70s upward with release of the chart breaking Jeunkôkú. Idonije left the band after the infamous incidence of soldierôs invasion of the Kalakuta Republic in 1977. When Benson Idonije left, BekoRansome-Kútìtook over the administration of the company with a new twist to the running of the organization. He placed Felá on a monthly salary since he wanted the organisation to run like a limited liability company. All the members of the band collected their weekly salaries (which was also tax deductable) from the accountant with Bekoôs approval. Commenting on his weekly pay package in an oral interview, BíódúnAdébíyi stressed:

You will never collect your salary at the shrine on Friday night without his (Beko) approval. I was earning N75.00 every week 
while I was paying N4.00 tax (Adébíyi, 2007).

Beko was also the medical doctor of the organization. Every member of the band enjoyed free medical services which were paid for by the organization.

\section{Band Leader}

He was the coordinator of the instrumentalists ${ }^{2}$ and leader of the instrumental section of the band. His function was to give direction to other instrumentalist when Felá was taking a solo during public performance. He also assisted with the coordination of the overall performance in his absence. He served as the spokesperson for the instrumentalists before the management and would report erring members to the leader for appropriate sanctions. His duty also included arrangement of instrumentalists on the stage before the arrival of the leader during performance tours.

Giving an account of his experience as the leader of the band from the early 80ôs till date, LekanAnimasaun (Baba Ani) stated that love for the profession was the driving force behind his continuous stay with the band. Apart from the role of leading the band in the absence of Felá, he was also involved in auditioning band members and recommending the successful ones into the band .Talking about the relationship he had with Felá in an oral interview, he explained that:

Felá had a lot of respect for me as the band leader. He never exhibited the ñI know it all attitudeò as displayed by some group leaders. Whenever there was a problem to be fixed, he would always call on me for advice on what to do. He was also open to correction in matters pertaining to the welfare of band members. That is the reason why we were very close when he was alive (Animasaun, 2006). 


\section{The Instrumentalists}

The Instrumentalists consist of at least twelve horn lines: two baritone saxophones, three alto saxophones, two tenor saxophones, and four trumpets. Felá played the tenor saxophone and the piano while another organist supported in the background. The band had two tenor guitar players and two bass guitar players with an array of traditional instruments like sèkèrè, agogo, àkúba, atumpan, and wood clappers. Each of the instrumental section had their own period of rehearsals with Felá before the general rehearsal session. This allowed them the opportunity to master the intricate section of the music being rehearsed.

It is interesting to note that gifted instrumentalists were enlisted in the band during the various phases of the development of Afrobeat. They included Tony Allen on the drums, Eddie Aroyewu, Túndé Williams and BíódúnAdébíyi on the trumpets, Kéjì Hamilton on the keyboard, Fred Lawal and Yínká Roberts on guitar, BabátúndéAnímásaun and YínnúsàAkínníbòsún on baritone saxophones, Tex Becks and Christopher Uwaifo on tenor saxophone, FémiAníkúlápòKútì on alto saxophone, Chris Onuorah on Àkúbà drums and ÀbáyòmíÀdìó on the congas.

\section{The Song Leader}

The vocal section of the music was headed by the song leader under Feláô instructions. Her responsibility included the selection of singers for performances. The selection was based on the singersôability to exert vocal influence on other members of the group. Moreover, series of rehearsal session were organised with the singers when Felá was busy with other sections. By now, she would have been given the lyrics and all the entry points, having rehearsed with the leader. All the singers were made to rehearse with her and any intricate aspect of the song is left for Felá to handle at the general rehearsal session. As the song leader, she occupied a conspicuous position on the stage to direct the singers and give the required boost needed by the singers. Quite often, she was saddled with the responsibility of selecting the costumes of the singers for each performance. The song leader $\hat{o}$ 
position of the band in the 70ôs and 80ôs was filled by Alake Anikulapo Kuti, one of Feláôs wives.

\section{The Singers}

Singing played a prominent role in Afrobeat band. As an integral part of the band, the singers provided the vocal accompaniment for the music. Their voices were characterised by distinct articulation, rhythmic precision, a sense of tonality, lucid expression, and intonation, since most of the lyrics are in call and response format. Furthermore, the singers must exhibit a clear understanding of what the lead singer is passing across. The various vocal dialogues in Afrobeat were well rehearsed by the vocal section in separate practice periods with Felá before performance. Felá expected every member of the band to know how to sing. In the course of the performance, the instrumentalists and dancers were expected to join the singers in the chorus section, thus giving the response a strong effect. The singers included KevweAníkúlápòKútì, Alake AníkúlápòKútì (the song leader), FehintolaAníkúlápòKútì, OmolaraAníkúlápòKútì and IhaseAníkúlápòKútì.

\section{The dance tutor}

The dance tutor trained the dancers on the various dance movements, steps and styles. He choreographed all the dance steps needed for the performance of the music and organised several dance classes for the dancers in order to aid their movements on the stage. Several dance tutors have occupied this position in the past but according to Baba Ani, the teacher that was employed in the eighties was AjayiOgunde ${ }^{3}$. The band leader would first listen to the music with Felá in order to fashion out all the movement for the particular music. Afterwards, the dancers would meet with the tutor privately in order to fine-tune the dance steps before the general rehearsal.

\section{The dancers}

The dancers who were mainly females formed an integral part of the band with the various gesticulations and choreographic 
displays they exhibit during every performance. The basic requirement of a good dancer in Feláô band was the ability to respond to the beat of the music with the movement patterns already established by the dance tutor. The upper and lower parts of the body must be flexible enough to move to the rhythmic patterns and sequences. Furthermore, the dancer must be able to identify the contextual factors surrounding the music being danced to and respond appropriately. This implied proper knowledge of the lyrics of the songs so that the basic movement of the dance was in tandem with the music. According to Femi AníkúlápòKútì in an oral interview, the first dancer in Feláô band was simply called Dele. This was also confirmed by Tony Allen who stated further that she had the magic of holding the audience spell bound with her erotic dance steps. She also started grooming other dancers in the early 1970ôs but left to join the organisation of Jùjú musician Ebenezer Obey.

The dancers were recruited from among the wives of Felá. A few were established dancers before coming to Feláôs house. Others had in-house training and performances at the shrine. However, selection (which is keenly contested among Feláô wives) was made by the dance tutor based on the aforementioned criteria. Since the dancers do not exceed fourteen in number, every effort is made by Feláô wives to be among the first fourteen. The names of the dancers include ÀdùníAníkúlápòKútì, FunmilayoAníkúlápòKútì, NajiteAníkúlápòKútì, OnilereAníkúlápòKútì, and SewaaAníkúlápòKútì.

\section{The Accountant}

The accountant was the financial controller of the band. His duty included taking records of both the income and expenditure of the band. With the approval of the manager and the endorsement of the leader of the group, he would pay the salaries of the workers in the establishment. His function also involved the supervision of the gate takings, the bar, and storekeeping. 


\section{The Sound Engineer}

The sound engineer was in charge of all the musical instruments and the electronic gadgets in the band. With other technical aids, he takes responsibility for the technical details of the group like the lightings, the audio and video recordings, electrical and electronic settings and sound mixing. He was also responsible for sound checking the instruments at every performance.

10. The stage manager. The stage manager ensured that everything that was needed for the performance, in terms of instruments, is available. At the end of the show, he ensured that all the instruments that have been used on the stage were carefully packed and stored for future use.

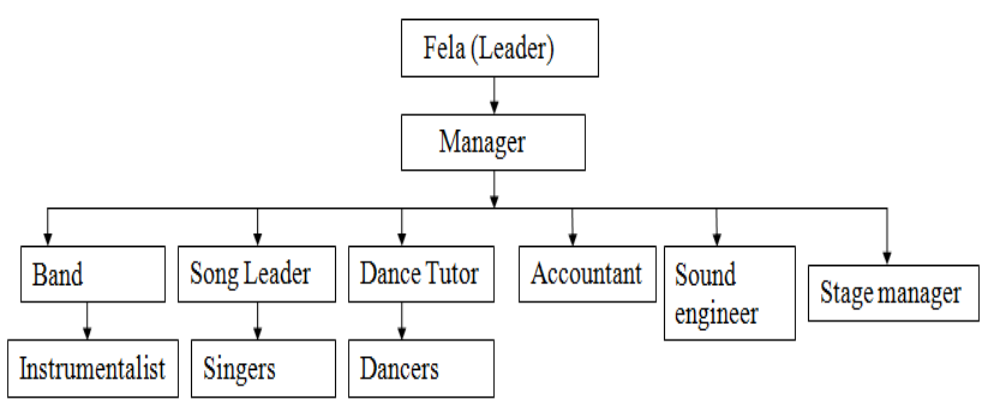

\section{Diagram showing the Organogram of Felá's Band}

\section{Recruitment and Training of musicians}

There was no formal method of recruiting members into Feláô band. However, the onus of selection lies withFelá. He had a flare for the best of hands and would do anything within his power to get them once he saw one. Recounting the way he came into the band, BabatundeAnimasaun ${ }^{4}$ (Baba Ani) remarked that it was destiny that brought him and Felá together. This happened when 
Felá came back from London in 1965. He read in the newspaper that Felá had formed a highlife-jazz band and at that time, he (Baba Ani) was a member of the Nigerian Broadcasting Corporation orchestra under the leadership of late FeláSowande, playing the tenor and baritone saxophone with the dance orchestra. It was on one occasion when he went to NBC studio in Ikoyi for rehearsal that he met Felá at the receptionist counter. Felá gave him an appointment for that same evening and after series of auditioning exercises on sight-reading and his instrument,he looked at Benson Idonije (who he fondly called Oyejo) and said ñOyejo, I will take himò. That was how he was recruited into the band in 1965 .

Commenting on the requirement for enlistment into the band in an oral interview, Baba Ani stated:

...the main requirement for acceptance into the band is dexterity in your primary instrument, a good sense of rhythm, and the ability to work with other instrumentalists. You must be creative and resourceful on your instrument (Animasaun, 2006).

Recalling how he was recruited in 1990 BíódúnAdébíyî (also called Batik) stated that Felá discovered him at a jazz club in Ikoyi when he was jamming with Jazz 38 band ${ }^{5}$. He played a solo piece on the trumpet when Felá came visiting and that was how he was invited to the band as a trumpeter.

Several scholars have given reasons why musicians enlist in a band. eOne of such reasons is the desire for acceptance and excellence in performance. Another reason postulated by Merriam (1989) is the economic benefit that such a band would bring to the musicians. However, all the instrumentalists interviewed maintained that they joined Feláôs band because they wanted professional recognition and acceptance. This is in line with Merriamôs (1964) assertion that:

complete acceptance depends upon public recognition of the musician as a musician whether or not this is accompanied by any set of payment (p. 125)

According to Adébíyi in an oral interview, every instrumentalist of the time saw performing in Feláô band as a rare privilege. He 
observed:

No matter what you play on the trumpet people will ask if you can play up to the level of Feláôs band boys. They believe that the only way you can prove to the world that you know how to play the trumpet is by joining Feláôs band. That made everybody who play trumpet long to play in Feláôs band. Just the recognitioné nothing else (Adébíyi: 2006).

This became the yardstick by which other instrumentalists of that time were assessed. Moreover, majority of the instrumentalists that served in Feláô band had other jobs apart from music. However, every member of the band was fixed on a weekly salary and honorarium after every show at the shrine. According to Batik, the instrumentalist is put on a weekly salary immediately he passes the audition with Felá. The set of musicians that made it a full time business are the singers and dancers. Even though Felá lived with them as his wives in the Kalakuta Republic, he ensured they were graded on skills and competence by his older wives (Alake and Lamiley) before taking central stage as singers. The final selection is left to the discretion of Felá.

A high level of musicianship was expected from the instrumentalists. Consequently, he taught them sight-reading in both tonic sol-fa and staff notations. Giving credence to this assertion was AbayomiAdio ${ }^{6}$. He was Feláô first conga drummer in the 1960s who before joining Feláô band, had played with the likes of Bobby Benson, Zeal Onyia, and Orlando Julius. He joined Feláôs band through one of his friends, Tony Allen, who had already been employed by Felá. Commenting on the training procedures of Felá during the KoolaLobitos era, ÀbáyòmíAdio submitted that Felá manifested from the beginning of his career the trait of a perfectionist by taking them all through a one year formal training on sight reading during the highlife jazz era. Since he wrote the scores of most of the instruments, the instrumentalists had to be taught how to read music notation. However, Abayomiôs case was different since Felá never arranged music for the conga 
and other drums. In an oral interview with the researcher, he stated that the discretion of the beat to be played was left to Abayomiôs judgment:

... he would tell me, r̃Easy, donâ worry. Listen to the music and anything you think fits in, put itò. So all the time, I decided what best fitted into the compositions (Adio, 2007).

\section{Rehearsal procedure}

The success of every performance starts at the rehearsal session. The former members of FeláôAfrobeat band interviewed (BabatundeAnimasaun, YinnusaAkinnibosun, BíódúnAdébíyî, DuroIkujenyo, Keji Hamilton, and Chris Onuorah) had glowing memories of the rehearsal sessions with Felá and agreed that the rehearsal sessions were the engine room where Afrobeat style was developed. Commenting on the rehearsal sessions in an oral communication, Baba Ani observed:

it was very hectic. Sometimes people like Uncle Steve, Rhodes ${ }^{7}$ would come to the rehearsal of Feláô band. The comment was ñFelá hope you wonâ kill these people in your band before they grow up or ageò, because it was very hectic. He was not joking with any aspect of his music, he could do anything. He was really a perfectionist (Animasaun, 2006).

The general rehearsal time was held twice a week at the African Shrine before a crowd of admirers. Furthermore, each section of the band had their own schedule of rehearsal. This would afford him the opportunity to treat the intricate passages found in each section. Felá adopted the procedure of rehearsing with each instrumentalist on a personal level. He could practise at home with the bass players and the guitarists. At other times he would call the drummer and the horn sections to rehearse at separate intervals. Then he would rehearse with the vocals and the dancers. Afterwards, he would call for a general rehearsal where he would 
synchronize the whole concept together. Recounting his experience during the personal rehearsal sessions he had with Felá, DuroIkujenyo observed that:

When it comes to rehearsals you see Felá as a very meticulous person. He was an orchestrator that would sit down in his house and actually work out the various parts of the instrument sections, using the keyboards. He insists on perfection in the sense that if you are the only person that could not get your part, Felá was ready to spend the rest of the rehearsal day on you alone (Ikujenyo, 2008) ${ }^{8}$

To Felá, every single instrument and performer was important. He instilled a sense of belonging and commitment to every instrumentalist by devoting ample time for all the members of the band.Apart from the band rehearsals, Felá had his own personal rehearsal time. According to Adébíyî, Felá would practice in the night till morning on the saxophone and organ. He explained further that Felá had an organ in the house that he used for his compositions. After working on all the lines on the organ, he would write them on paper and distribute same to members the following rehearsal time.

The discipline exhibited by members at rehearsals helped the successful performances of the band over the years. The exposure Felá had in western musical practices, coupled with the strict discipline he imbibed as a child from his parents all helped him in inculcating the driving spirit for success in members of his band. According to Chris Onuorah, every act of indiscipline attracted a fine which was immediately paid by the offender. Such acts included lateness, cheating, gross absenteeism, and the failure of an instrumentalist to take off at his count. On the disciplinary measures of Felá at rehearsal YemiAkínníbòsún commented:

Felá had a musical ear to pick what is not right in the music. if someone was playing what he knew was wrong, he could stop and pinpoint who made the mistake and send the person out of the stage after several warnings. This would 
instil a sense of duty and commitment on other

members of the band. (Akínníbòsún, 2006)

Even though Felá was a strict disciplinarian, he respected the views of other members of the band. He would normally ask for the impression of members on his compositions. It could either be on the chords, the phrasings, the lyrics, the rhythmic pattern and so on. Citing an example, Baba Ani said that he was the one that suggested the words ñotítókoròomoaráyé ò fe, béefé, béèfé, èmi á wítèmiò and it was accepted and included in the song. Below are the excerpts:

\author{
jéinwítèmisé o \\ òwòkìifốwólórùn \\ jéinwítèmi \\ òtítókoròomoaráyé ò fe o \\ béefé, béèfé \\ èmi á wítèmi
}

Another striking feature on Feláô relationship with his members was his liberal nature. Even though he expects unwavering loyalty from the members, he would not prevent any member of the band from doing his or her own personal music project as long as it wouldnâ affect their assignments in the band. He would even assist in making the project a success. Recounting the project he had when he was in Feláô band, DuroIkujenyo said all he needed was to ask for Feláô permission to perform with the group and Felá consented. He also allowed his members like Baba Ani (1995) and Tunde Williams (1994) to release their own albums. Baba Ani once again commented that Felá played the keyboard in his songs.

\title{
Afrobeat Band in the $21^{\text {st }}$ century
}

There is no denying the profound influence Felaôs ensemble arrangement had on popular musicians within and out the African continent. According to Veal, (2004) Fela's influence may be felt throughout various regions of jazz practice including the avantgarde, neoclassicist and fusion movements. He stressed further that his music expertise and managerial ability has been the primary catalyst for the development of a movement of younger Nigerian jazz influenced players. Feláôs two sons; Femi and Seun 
are continuing in their fatherôs tradition of playing every week in the New African shrine and staging concerts around the world, thus promoting Afrobeat at home and abroad. Femi has forged a distinctly urban sound that melds afrobeat with elements of hiphop, house and techno music. Widely endorsed by the international media as afrobeatốs new mantle bearer, Femiôs contemporary reinterpretations of the musical ideas he first encountered as a saxophonist in his fatherôs Egypt ổ0 band has earned him audiences in Europe and America, as well as a Grammy Award nomination in the Best World Music category for his 2001 album, Fight to Win (Dosunmu, 2010). Interestingly, he has stuck to the ensemble style of his father.

The technological advancement in music has also rubbed on contemporary performance. Afrobeat artistes now have the development of digital music to their advantage. Even though Fela did not use studio effects in his recordings when he was alive, the present crops of Afrobeat musicians are utilizing the advanced technology in studio technique to create an equally entertaining music. Afrobeat musicians from abroad like the Antibalas make use of massive studio effects, thus giving it a mass appeal among the youths and downplaying the big band tradition Felá was known for. Taking a look at the future of Afrobeat, Shola Olorunyomi states:

I foresee the reduction of the big band tradition. With the reduction of the big band tradition, chances are that the structure and style of the music is also going to be affected. We may not necessarily have the Fela theme in terms of the structure and the time sequence but the overall texture will be retained. This is already happening among the new Afrobeat musicians, especially outside of Nigeria. This is because it is difficult to sustain a band of Felaôs size in Europe. Olorunyomi $(2005 ; 27)$

Fela provided a blue print that others are trying to expand upon. In an interview with Dosunmu (2010) Francisco, Ezra Gale, founding member of a band called Aphrodesia expressed this view: 
one thing I noticed about a lot of these [afrobeat] bands is that a lot of them reallysound pretty much just like Fela. I think thatôs the blueprint everybody is workingfrom. And, you know, with our band, weôe kind of trying to move a little bit beyond that, you know, just kind of taking it in some other directions. We mix in some otherstyles that I donâ normally see these other bands doing, you know, stuff from likeGhana and Zimbabwe and some other American funk and jazz styles (78)

There is a fraternity of common grounds between Afrobeat artistes and other popular musicians. The cold war and battle for relevance that pervaded the music scene during Felâ̂ time seems to be abating as musicians now share a common platform to sing their songs irrespective of the typology or differences in message. This is made possible through the yearly Afrobeat remembrance concert /festivals both in Nigeria and Europe. The concert in Europe is tagged ñRepublicafrobeatò. Established in August 2002, the programme was initiated by a small group of Afrobeat fans in Madrid. In Nigeria, the commemoration concert was tagged ñFelabrationò. According to Tunde Oshnubosi ${ }^{4}$ (a.k.aLaface) Felabration is all about celebrating the life, music and legacy of the great Afro beat legend, Fela Anikulapo Kuti, adding that the event is meant to immortalize the man Fela Anikulapo Kuti as an accomplished poet, activist, prophet of our time and great musician. It has now become a yearly event with sponsors coming from both the private and public enterprises. The first concert drew notable stars like the South African reggae maestro Lucky Dube and Nigerian musicians like Dbanj, Weird MC, Alariwo of Africa, and the prince of Afrobeat, Femi Anikulapo Kuti.

\section{Conclusion}

The choice of musicians, singers, dancers and other ad hoc staff was pivotal to the smooth running of the organization. Furthermore, their devotion and commitment to the band was one 
major reason for its successes. The men and women that served in Feláôs band were selfless and sometimes had to put their life on the line in their bid to achieve his ambition as a musician. Without them, there would not have been any Afrobeat and so they are deserving of commendation.

\section{End Notes}

1. In Feláô lifetime, the position was occupied by Benson Idonije (1967-1977) and BekoRansomeKuti (1977- 1995).

2. The first band leader was Tony Allen. He was succeeded by BabatundeAnimasaun. Tony Allen was the band leader

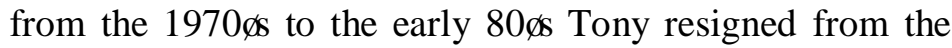
band after the Berlin Jazz festival. Baba Ani remains the band leader of Feláôs band till date.

3. Unfortunately, efforts to get AjayiOgunde in an interview proved abortive as Baba Ani had lost track of his where about. However, the people interviewed were unanimous with the fact that he was the official choreographer of Felaôs band

4. Interview with LekanAnimasaun (Baba Ani) (2006).

5. The band was owned by Tunde and Frances Kuboye. Frances was Feláô cousin.

6. An interview with Abayomi Easy Adio (2007). He is presently a clergyman at the Celestial Church of Christ Ikeja Parish.

7. A veteran musician in Nigeria.

8. An interview with Ikujenyo (2008) 


\section{References}

Collins, J. (2015). Fela: Kalakuta Notes Middleton, MN: Wesleyan University Press.

Coker, N. (2004).A study of the music and social criticism of African musician, Fela Anikulapo-Kuti. New York: Edwin Mellen Press.

Dosunmu, O. (2010) Afrobeat, Fela and beyond: Scenes, style and ideology. Ph.D thesis, Faculty of Arts and Sciences, University of Pittsburgh.

Moore, C. (1982). This Bitch of a Life- FeláAníkúlápòKútì. London: Allison And Busby Press.

Merriam, A. (1989). Traditional Music of Black Africa.Indiana:Indiana University Press (1964). Anthropology of Music. Evanston: Northwestern University Press.

Olorunyomi S. (2005). Fela and the imagined continent.Ibadan: I.F.R.A Publications

Veal, M. (2004).Fela: The life and times of an Africanmusical icon. London: Temple University Press.

Vincent, R. (1996).Funk: The Music, The People, and The Rhythm of the One. New York: St. Martin's Press

Wallach, J. (2008). Modern noise, fluid genres: popular music in Indonesia, 1997-2001. London: University of Wisconsin Press. 